\title{
Research Paper An economic analysis of cost, return and profitability of groundnut across leading states of India
}

- Prasanna Kolar, P. K. Awasthi and Ankita Sahu

See end of the paper for authors' affiliations

Correspondence to :

Prasanna Kolar

Department of Agricultural

Economics and Farm

Management, Jawaharlal

Nehru Krishi Vishwa

Vidyalaya, Jabalpur (M.P.)

India

Email: hiprasannakolar@, gmail.com

\section{Paper History :}

Received : 17.05.2020;

Revised : 25.07.2020;

Accepted : 26.08 .2020
ABSTRACT : The current study was undertaken with the objectives to estimate the dynamics of cost, returns, profitability and break-even production of groundnut across the leading states of India. For that secondary data were collected from Directorate of Economics and Statistics for the period 1996-97 to 2015-16. For statistical analysis tools like relative change, compound growth rate and cuddy della valle index were used. The study found that $\operatorname{Cost} \mathrm{A}_{1}$, $\operatorname{cost} \mathrm{A}_{2}$, $\operatorname{cost} \mathrm{B}_{1}$ and $\operatorname{cost} \mathrm{C}_{1}$ of groundnut in Gujarat and $\operatorname{cost} \mathrm{B}_{2}$, cost $\mathrm{C}_{2}$ and $\operatorname{cost} \mathrm{C}_{2}$ revised in Andhra Pradesh were found to be increased at higher annual growth rate during the study period than any other states. These cost concepts showed high instability for almost all the leading states. Groundnut was more profitable in Gujarat due to higher net income and B:C ratio than other states. Differential yield and the difference between the cost of production and minimum support price were found better among Gujarat and Tamil Nadu states. In other states, the actual yield was lower than break-even and the cost of production was higher than minimum support price leading to the losses for the groundnut growers.

KEY WORDS : Cost of production, Profitability, Break-even yield, Minimum support price

How To Cite This PAper: Kolar, Prasanna, Awasthi, P.K. and Sahu, Ankita (2020). An economic analysis of cost, return and profitability of groundnut across leading states of India. Internat. Res. J. Agric. Eco. \& Stat., 11 (2) : 278-284, DOI : 10.15740/HAS/IRJAES/11.2/278-284. Copyright@2020:Hind Agri-Horticultural Society. 